\section{German Higher Education in a European Context}

\section{Ulrich Teichler}

Ulrich Teichler is professor and director of the Center for Research on Higher Education and Work, University of Kassel, Germany. Address: E-mail: teichler@hochschulforschung.uni-kassel.de.

$\mathrm{R}$ esponsibility for the provision of higher education has always varied from country to country. In continental European countries it has traditionally been viewed as the duty of the state. In several of these countries, governments have even funded institutions not under direct government control. In the United Kingdom, by comparison, institutions-though state-approved by royal charter-have been considered to be independent entities that fund themselves through endowments, state support, and tuition fees. In the United States, private and public institutions have had much in common regarding funding, management, and supervision. Other governments have provided the nucleus of higher education, while private institutions have supplemented the core.

In the wake of higher education expansion, growing fiscal problems, and the increasing popularity of neoliberal economic doctrines, private funding and the privatization of higher education institutions have gained ground in many countries traditionally dominated by public higher education. The debate over private and public funding, however, often involves a confusing mix of three issues: student costs, the role of public subsidies, and the level of government supervision.

\section{Student Costs and Public Subsidies}

The rationale behind public and private subsidies can be explained first by looking at the costs individual students incur. A recent study shows that tuition fees are charged in about half of the member states of the European Union and tend to be very small as compared to those charged by the national universities in Japan or by state universities in the United States. The proportion of students receiving grants and loans to cover living expenses varies among EU countries from less than 5 percent to more than 90 percent. Levels of public subsidies seem to vary depending on the concept of the social role of students.

Some countries see students as children in society's family. That family is expected to care for the students, and the students' study opportunities depend on the family's ability and readiness to pay (e.g., Greece). Students may also be seen as children in a family system with strong welfare components. In many cases, where parental income is low, the public steps in with grants and loans (e.g., until recently, the United Kingdom). Alternatively, students may be viewed as investors in their future. A student's future prospects are what count, not the current social situation. Not a single EU country pursues this model consistently, but some components of the model can be observed in Sweden and the Netherlands. Finally, a society may view students primarily as prospective workers and young citizens. Substantial grants are provided irrespective of parental income or students' potential income after graduation (e.g., Denmark and Finland).

While these beliefs are broad generalizations about various societal images of students, they strongly influence decisions on the appropriate levels of public subsidies to both public and private higher education institutions.

\section{The debate over private and public fund- ing, however, often involves a confus- ing mix of three issues: student costs, the role of public subsidies, and the level of government supervision.}

\section{Supervision of Higher Education}

The distinctions over government supervision between public and private institutions are not always obvious. For example, an institution's legal status may be neither clearly public nor private, making it a matter of interpretation whether the institution is semipublic or semiprivate. In other cases, the official status might be private, but the government may clearly retain a supervisory role. There are also umbrella organizations of various colleges that are partly private and partly public (e.g., Fachhochschulen in Switzerland and ammatikorkeakoulu in Finland). Finally, private institutions might be publicly funded. This holds true for most universities in the United Kingdom, private universities in the Netherlands and Belgium, and for colleges of theology in Germany.

The Organization for Economic Cooperation and Development (OECD) classifies higher education institutions into three categories: public, governmentdependent private, and independent private institutions. Most German, French, U.S., and Australian institutions are in the first category. Most Dutch and British institutions fall into the second category, and most Japanese institutions are in the third category. The 
distinction between the second and the third category lies primarily in the level of government funding. Public universities enrolled 81 percent of all university students and 69 percent of students from other programs in 1998 in OECD member countries; government-dependent private universities enrolled 9 percent of university students and 18 percent of students from other programs; and independent private universities enrolled 10 percent of university students and 13 percent of students from other programs.

\section{The proportion of students receiving grants and loans to cover living ex- penses varies among EU countries from less than 5 percent to more than 90 percent.}

Private Higher Education in Germany

In recent years, reports have mushroomed in Germany about the establishment of private higher education institutions. Private institutions generally have been welcomed because they are perceived as contributing to the diversity of higher education and providing administrative and educational models that might trigger reforms in the public sector.

According to OECD statistics, all German universities are public. However, in 1998 official German documents listed 75 (22 percent) of the approximately 344 higher education institutions in Germany as "nongovernmental" and as accommodating about 2 percent of all students. These institutions can be categorized as church-related colleges of theology or social work; private universities pursuing a specific educational philosophy; outsourced segments of public institutions of higher education (i.e., specific divisions that generate income or need specific administrative flexibility not provided in the public sector); and specialized colleges for business studies and a few other fields, primarily funded by donations and tuition fees.

The last two categories emerged in the 1990s and often claim to be different from public universities in several respects. Some underscore a utilitarian approach and state that the curriculum is geared toward superior job marketability. Several call themselves "European" or "international" universities, showcasing a high ratio of foreign students and staff and requiring all students to spend a study period abroad. Many of these colleges attempt to distinguish themselves by declaring to be student-friendly campuses with close faculty-student relationships. Several of these colleges contend that they are "elite" institutions. Finally, some claim to have a very flexible and efficient management style.

All higher education institutions in Germany must apply for approval from the respective Land in which they are located. Public institutions of higher education are supervised by the 16 Länder governments. No approved private university in Germany is owned by a foreign entity. Efforts are being made, however, to establish a university in cooperation with a private U.S. university.

Despite the tremendous growth in the number of private institutions and other privatization efforts in Germany, these endeavors have turned out to be less successful than public debate might suggest. Few donations have been received and institutions have been hesitant to charge high tuition fees.

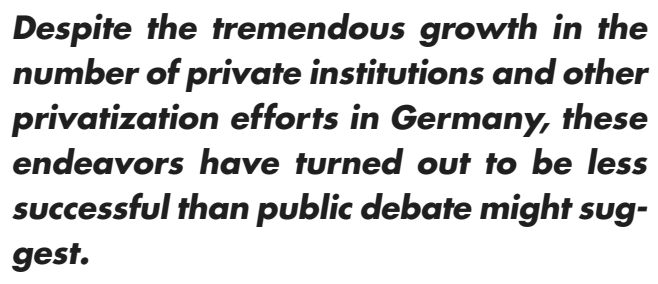

Components of Privatization in the Public Sector

Moves toward privately funded higher education institutions are weak and tentative in Germany and most Western European countries. Rather, public institutions are gradually taking on some components of market regulation and privatization. Stagnant government funding, rising costs, and increasing student numbers are forcing higher education institutions to look for other sources of income. Governments are simultaneously moving away from complete control of higher education toward less direct regulation through contracts, indicator-based funding, and evaluation. Generally, higher education is being more strongly shaped by competition and incentives than in the past. These factors have led to a growing diversification of funding patterns in many countries. In Europe, the privatization of select elements of public institutions appears to be the dominant trend, while the establishment of independent private institutions remains the exception.

This article is based on a presentation made at Waseda University, Tokyo, on invitation of the Research Institute for Independent Higher Education. 